\title{
Mensagem aos alunos da primeira turma da Faculdade de Medicina de Ribeirão Preto - USP
}

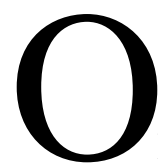

próximo evento comemorativo do aniversário de 55 anos da Faculdade de Medicina de Ribeirão Preto (FMRP) ocorrerá no dia 23 de fevereiro de 2008, quando, com alegria, orgulho e carinho, a nossa escola receberá a visita de 26 (dos 43) médicos graduados na primeira turma do Curso de Medicina.

A primeira turma de alunos da FMRP (19521957) comemora meio século de exercício da profissão, meio século de vivência das alegrias, angústias, frustrações e realizações inerentes à prática médica. Depois de meio século, a experiência torna tudo mais fácil, mas sempre aparecem casos desafiantes e periodicamente surgem novas doenças, o que impele a estudar e a aprender sempre mais. Assim, todo médico é um eterno estudante. E essa vontade de aprender mantém a juventude.

Nossos colegas voltam meio século mais velhos, com meio século a mais de experiência na arte de viver. Imagino que agora só sofram por causas importantes e tenham aprendido a sentir alegria com as pequenas coisas do dia-a-dia. Imagino que quase todos tenham a felicidade de ter descendentes e que tenha muito a ensinar a cada um deles, as amizades, antigas ou recentes, sejam mais sólidas e mais tranquiilas. Mas espero que os amores, antigos ou recentes, sejam ainda acompanhados de euforia de uma certa intranqüilidade - porque isso é juventude.
Imagino que as conversas serão intermináveis, porque cada um tem meio século de história para contar. Imagino que esta reunião de turma será momento de emoções, de abraços, de risos e de lágrimas de felicidade - porque isso é vida.

Imagino que esta reunião também será um momento de recordações - de afetos e de simples conhecidos, de rostos jovens e de faces cheias de rugas, de reuniões na beira do lago, dos bailes no Ginásio de Esportes, das enfermarias da Santa Casa, do Centro Acadêmico Rocha Lima, de animadas festas nas repúblicas e de cansativos serões na véspera das provas. Será bom recordar - porque só se recorda o que é significativo na nossa vida.

Imagino que esta reunião também será um momento de saudade de pessoas queridas, distantes, pelas circunstâncias da vida ou pela inevitabilidade da morte. Mas a saudade também é um sentimento positivo - porque só se tem saudade de quem enriqueceu a nossa vida.

Assim, caros colegas, desejo para todos vocês um momento de muita recordação, muita alegria, muito afeto, muita vida e muita juventude. E que a vida e a felicidade persistam por longos anos.

\section{Profa. Dra. Maria de Lourdes V. Rodrigues}

Presidente da Comissão de Comemoração dos 55 anos da FMRP-USP e

Presidente da Comissão de Cultura e Extensão Univeristária Professora Associada do Departamento de Oftalmologia, Otorrinolaringologia e Cirurgia de Cabeça e Pescoço; 